\title{
Democracy, Popular Sovereignty, and Judicial Review
}

\author{
Robert Post $\dagger$
}

It is eminently appropriate that the Inaugural Lecture of the Brennan Center Symposium on Constitutional Law be delivered by Frank Michelman, for no one could be more deserving or more enlightening. It is also appropriate that Michelman should choose as his topic the tension between democracy and constitutionalism, for this tension has been the central problem of American constitutional theory since the onset of the twentieth century.

Constitutional theory is an odd enterprise. In contrast to certain political philosophies that aspire to systematic analysis based on first principles, constitutional theory primarily seeks to expose and clarify the principles immanent within the practice of constitutional adjudication. For this reason constitutional theory cannot posit itself behind a "veil of ignorance"1 or within an "ideal speech situation." Constitutional theory is always, so to speak, within our tradition and our history; it is parasitic on the very practice it seeks to explain. The achievements of revered and influential Justices, like William J. Brennan, whom we are here justly convened to honor, must therefore be taken as part of the data to be explained. In this sense, Michelman is right to place Brennan's work at the center of his investigation.

\section{I}

It is, however, a tricky business to expose and clarify the principles immanent within a practice. This is because sophisticated practices, like constitutional adjudication, tend to be complex and filled with unresolved internal tensions that leave ample room for critical disagreements. ${ }^{3}$ Indeed, as Alasdair MacIntyre has written, "A living

Copyright @ 1998 California Law Review, Inc.

$\dagger$ Robert Post is Alexander F. \& May T. Morrison Professor of Law, University of California, Berkeley School of Law (Boalt Hall). He was a law clerk for Justice William J. Brennan Jr. during the October 1978 term.

1. John Rawls, A TheORY OF JUSTICE 136-42 (1971).

2. JU RGEN HABERMAS, Legitimation CRISIS 110 (1973).

3. For a good statemcnt, see Michael Walzer, Interpretation and Social Criticism $35-66$ (1987). 
tradition ... is an historically extended, socially embodied argument, and an argument precisely in part about the goods which constitute that tradition." To pursue constitutional theory is not (as a general matter) to transcend or settle such arguments, but to engage them with a theoretical clarity, range, and abstraction that will hopefully prove useful to those who perform or wish to understand the actual work of constitutional adjudication.

The tension between constitutionalism and democracy identified by Michelman is a classic example of a central, ongoing argument within the practice of constitutional adjudication. Michelman accurately identifies "constitutionalism" as involving "a 'law of lawmaking' ... that controls which further laws can be made and by what procedures." $\mathrm{He}$ also convincingly identifies "democracy" with the idea of "[p]opular political self-government-the people of a country deciding for themselves the contents of the laws that organize and regulate their political association." American constitutional theory has struggled throughout this century to reconcile constitutionalism with democracy.

The parameters of any such reconciliation must be set by paradigmatic instances of actual constitutional adjudication, which form the basis upon which theoretical argumentation can proceed. From this perspective, however, there seems to be something strange about the way in which Michelman has formulated the issue. Michelman refers to a "necessity" that underlies the "irrepressible impulse to hive off fundamental-law determinations from the procedural purview of democracy" and that even "entirely bars democracy from a decisionspace where it would seem urgently and rightly to want to go, that of deciding the contents of a country's most basic laws, its laws of lawmaking." Yet within the practice of constitutional adjudication there are obviously paradigmatic instances, left unexplained by this conclusion, that subordinate constitutional meaning to the peremptory and even arbitrary direction of popular will.

Imagine, for example, that an amendment to the United States Constitution were to be properly and duly proposed by two-thirds of both houses of Congress, and properly and duly ratified by the legislatures of three-fourths of the States. Imagine that the amendment repeals the Twenty-Sixth Amendment and unambiguously provides that no one who is not yet 21 years of age can vote for any federal official. ${ }^{8}$

\footnotetext{
4. Alasdair MACINTYre, AfTER Virtue 207 (1981).

5. Frank Michelman, Brennan and Democracy, 86 CALIF. L. Rev. 399, 400 (1998).

6. Id. at 430 .

7. Id. at 420 .

8. The Twenty-Sixth Amendment provides: "The right of citizens of the United States, who are eighteen years of age or older, to vote shall not be denied or abridged by the United States or by any State on account of age."
} 
Suppose, finally, that a citizen of the United States who is eighteen years of age and who wishes to vote in an upcoming Presidential election brings suit in federal court for the right to vote.

I take this to be a paradigmatically easy case, ${ }^{9}$ meaning that any judge who would decide for the plaintiff could be said not quite to understand the practice of constitutional adjudication. This would be true regardless of the judge's personal beliefs, political philosophy or constitutional convictions. The judge might even consider the new constitutional amendment to be wrong-headed and anti-democratic. But she would nevertheless rule against the plaintiff on the ground that the new amendment reflects the popular will of the people as measured by the procedural standards of Article $\mathrm{V}$, and that the amendment is therefore properly enforceable as constitutional law. In such a case, popular sovereignty manifestly trumps constitutionalism.

Of course I have in my example loaded the dice by postulating a recent and unambignous constitutional annendment. ${ }^{10}$ The kinds of cases that concern Michelman, and that have concerned most constitutional theorists, are in fact quite different. They tend to involve old constitutional provisions with general and equivocal language, like "cruel and unusual punishments," "the equal protection of the laws," "due process of law," or "the freedom of speech." Michelman is correct to conclude that our history of constitutional adjudication renders it genuinely implausible to regard the interpretation and application of such constitutional provisions as carrying the authority of popular will, even though these provisions were once popularly enacted. ${ }^{11}$ So long as these provisions continue to provide grounds for invalidating expressions of popular will manifested in ordinary legislation, the tension identified by Michelman between constitutionalism and democracy does indeed rise insolubly to the fore.

\section{II}

At the conclusion of his paper, Michelman proffers a "surmise" about how Brennan himself might resolve this tension. The surmise rests on the assertion that democracy need not entail the requirement that persons make (or participate in making) the laws by which they are governed. Instead it is said that a person who willingly abides by the laws "'out of respect' for them, because she finds on reflection that

9. See Frederick Schauer, Easy Cases, 58 S. CAL. L. Rev. 399 (1985).

10. I have loaded the dice in other ways as well. The example postulates an amendment that, while itself an interpretation of democratic principles, is not in flagrant and radical contradiction to fundamental and generally accepted democratic principles. Imagine by contrast a clear constitutional amendment that authorizes life tenure for the President. Such an amendment would expose the tension between democracy and popular sovereignty that I discuss infra at Part V.

11. See Michelman, supra note 5, at 415 . 
they are just, or fair," is "in a state of self-governinent, in as full a sense as we can reasonably hope to find in politics."12 It is not clear whether Michelman himself accepts this position; he maintains a judicious discretion on the question, although there is some textual evidence that Michelman is not ultimately satisfied with it. In my view, however, the position ought to be definitively repudiated.

The position rests on the claim that there exist "procedureindependent standards of rightness," so that respect for constitutional judgments cannot depend purely on procedure-dependent criteria that measure the popular will, ${ }^{13}$ like the standards of Article $V$ that would validate the constitutional amendment I imagined in the previous section. Instead,

the attributes in a set of fundamental laws that would command your respect would be as follows: First, it would have to appear to you that a maximum feasible effort is constantly being made to get the fundamental laws right. This ... includes getting their major interpretations right. Quite conceivably, this maximum feasible effort could ... include provision for a tribunal whose special business and concern it is to decide the interpretations. Second, this maximum feasible effort to get the fundamental laws right would have to include arrangements for exposing the empowered fundamental-law deciders to the full blast of sundry opinions and interest-articulations in society, including everyone's opinions and articulations of interests. Note that what now matters to you about having your own opinions and interestarticulations registered is not some bit of leverage you exercise over what gets decided, but rather the presumptive epistemic value of your contributions to the debate....

Suppose you hold the ... belief that the preceding two conditions for the production of fundamental laws (and their interpretations) are currently satisfied. You, then, can abide by the fundamental laws (including major interpretations) willingly, out of respect for them. Are you not then freely governing yourself, at least so far as politics are concerned? ${ }^{14}$

Michelman believes that if a Justice like Brennan were to attempt to reconcile his work of constitutional interpretation with democratic selfgovernance, he would have to accept these two structural conditions. Merely for the sake of terminological convenience, I shall call these conditions "Michelman's model."

One premise of Michelman's model is that a Justice's judgments are generally accepted as "just, or fair," or "right." We need to

\footnotetext{
12. Id. at 424 .

13. Id. at 424-25.

14. Id. at 425-26.
} 
inquire, however, how the model will function with respect to those who do not accept this premise. The point is important, because it raises a central problem of collective self-governinent that goes back at least to Rousseau. ${ }^{15}$ The problem revolves around the question of how, in the face of manifest and indissoluble differences, we may be said to govern ourselves through collective self-determination. Why is every majoritarian enactment not also an act of oppression against a minority? Or, to put the same question another way, how is the agent of collective selfdetermination to be constructed?

In response to this problem, Rousseau postulated that the particular will of each and every citizen should be fused with the general will of all, so that, in obeying the general will, each "obeys no one but himself, and remains as free as before."16 By assuming that a Justice's judgments are accepted as "just, or fair," or "right," Michelman essentially postulates the saine fusion of particular and general wills as did Rousseau. If we agree that a great Justice like Brennan has correctly interpreted our fundamental law, then our particular will is, in fact, in conformity with the general will as enacted in Brennan's judgments. To obey these judgments is thus to obey ourselves, so that, as Michelman accurately observes, we can be said to be "in a state of self-government, in as full a sense as we can reasonably hope to find in politics."

But many have charged Rousseau with willful unreality in postulating a determinate fusion between the particular wills of individual citizens and the general will of the state. Michelman's model is appropriately subject to the saine critique. For however great Justice Brennan may be, and I am prepared to go very far on this score, ${ }^{18}$ it still remains true that his work is controversial and that it is not accepted as "just" or "right" by large segments of the population. The saine would be true of the work of any Justice. This is a consequence of what John Rawls has called the wide "diversity of conflicting and irreconcilable-and what's more, reasonable-comprehensive doctrines" ${ }^{\prime \prime}$ that characterizes modern societies.

The question, then, is how the tension between constitutionalism and democracy may be reconciled with respect to the many persons who do not share a Justice's judginents about our fundamental law. Although agreement with particular constitutional interpretations may illuminate how specific individuals can coine to identify with

15. See Jean-Jacques Rousseau, The Social Contract (Maurice Cranston trans., Penguin Books 1968) (1762).

16. Id. at 60 .

17. Michelman, supra note 5, at 424.

18. See, e.g., Robert C. Post, Justice William J. Brennan and the Warren Court, 8 Const. COMMENT. 11 (1991).

19. John Rawls, Political Liberalism 36 (1993). 
constitutional judgments, it can not explain how a diverse nation can come to do so.

\section{III}

Michelman's model seems to intimate a response to this problem that moves slightly in the direction adopted by some modern critics of Rousseau. Finding it implausible to postulate that the particular wills of individuals can be determinably identified with the specific enactments of the state, these critics have suggested that democratic self-government requires that the particular wills of individuals be connected instead to the system by which these enactments are created. They have thus proposed that law making be rendered dependent upon public opinion, and they have postulated that a necessary condition for citizens to identify with public opinion is the guarantee that all can freely participate in the public deliberations by which public opinion is formed. ${ }^{20}$ Such democratic participation allows for the energence of a collective "agent" that can engage in the process of self-determination.

Michelman's model hints at a system that is very different, and yet that also aims to assure democratic self-determination even in the absence of agreement about the content of specific laws. Michelman specifies two conditions for this system: (1) the existence of a tribunal "whose special business and concern it is to decide the interpretations," and (2) a set of arrangements for exposing meinbers of this tribunal to "the full blast of sundry opinions and interest-articulations in society." ${ }^{21}$ Whereas the system advanced by those who locate democratic self-governance in the creation of public opinion stresses the potential participation of citizens in the formation of the laws by which they are to be governed, Michelman's model explicitly excludes this notion of participation. The precise question, therefore, is whether the structure proposed by Michelman can be said to reconcile constitutionalism with democracy in the absence of agreement as to the outcomes of particular constitutional judgments.

Michelman's model is actually quite analogous to the adversary system, at least as that system has been interpreted by scholars like Lon Fuller. ${ }^{22}$ The adversary system also contains a tribunal dedicated to the proper interpretation and application of the law, and it also sponsors advocates who have the epistemic function of ensuring that before a court reaches judgment "each side of the controversy be carefully

20. See Robert C. Post, Constitutional Domains 184-87 (1995).

21. Michelman, supra note 5, at 425.

22. See Lon L. Fuller, The Adversary System, in Talks on American Law 30-43 (Harold Joseph Berman ed., 1961). 
considered and be given its full weight and value."${ }^{.23} \mathrm{We}$ might willingly concede that these conditions roughly establish the legitimacy of judgments reached through the adversary system, as partisans like Fuller evidently believe that they do; indeed, Michelman does sometimes speak as if he were addressing "the problem of political legitimacy."24

But no one with whom I an familiar, and certainly not Fuller, has gone so far as to claim that these conditions suffice to justify characterizing the adversary system as a structure of democratic self-governance. While we often refer to the parties to a lawsuit as subject to a court's jurisdiction, we do not say that they govern themselves through the exercise of a court's jurisdiction. Or, if we were in special circumstances inclined to press such an odd claim, we would undoubtedly support it by reference to the fact that the parties, in their capacities as citizens, have participated in the formation of the very laws applied by the court. But it is precisely this latter consideration that Michelman's model wishes to exclude.

If adversary litigation most precisely fulfills the structural conditions advanced by Michelman, and if the parties to such litigation cannot be said to govern themselves through the pronouncements of a court, then neither can the entire population of the country be said to govern itself through the constitutional interpretations of the Supreme Court. That is why opposition to the Court's constitutional jurisprudence almost always has taken the form of attacking the Court's judgments as anti-democratic. During the 1920s, for example, when the Taft Court was vigorously resurrecting substantive due process, those who disagreed with the Court's constitutional interpretations did not view the Court as an instrument of self-governance, but instead attacked it as an "Unreformed House of Lords,"25 an "absolute despotism"26 that "militates against every conception upon which democratic governments are supposed to be based."27

If these characterizations seem exaggerated, imagine a contemporary Court staffed by Justices who, though competent, dedicated, and subject to "the full blast of sundry opinions and interest-articulations in society," nevertheless persist in pursuing a jurisprudence deeply at odds with your own. Imagine a Court of nine Justices McReynolds. I very much doubt that you would regard such a Court as an instrument of self-governance, despite the fulfillment of the two structural conditions proposed by Michelman.

\footnotetext{
23. Id. at 31 .

24. Michelman, supra note 5, at 424.

25. Supreme Court Nullifies People's Will, The N.Y. CALI, June 16, 1922, at 1.

26. Justice Ford Backs La Follette Ticket, N.Y. TrMes, Aug. 31, 1924, at 1.

27. Meyer London, The Veto Power of the Supreme Court, in AM. Federationist, Mar. 1923,
} at 225 . 
This suggests that Michelman's model fundamentally. depends upon the Court getting its major interpretations right. When we do not believe that the Court has correctly interpreted the Constitution, Michelman's two additional structural conditions are themselves incapable of generating the value of democratic self-determination. At most, these conditions can establish only political legitimacy.

\section{IV}

Michelman is certainly correct to flag the problem of how "getting it right" relates to the achievement of democratic self-governance. Even if a state were to subordinate lawmaking to public opinion, and even if all citizens were free to participate in the formation of public opinion, a particular group within the state that found itself perpetually outvoted, ignored, and alienated might well question whether the state were an appropriate vehicle for democratic self-governance. The group might even consider seceding from the state and founding its own democratic polity. This illustrates that a system of free and open democratic participation is a necessary but not a sufficient condition for democratic selfgovernance. Persistent and fundamental disagreement with other citizens may preclude the identification with the state that a system of open democratic participation is precisely established to promote.

It is important, however, to specify exactly how the fact of social disagreement intersects with the creation of democratic legitimacy. If democratic self-government requires that citizens identify with a system of open participation in the formation of public opinion, democratic legitimacy is correspondingly rendered independent of the particular legislative outcomes of that system. This independence allows democratic legitimacy to fit more or less comfortably with the "irreparable reasonable disagreement" that characterizes modern heterogeneous states. ${ }^{28}$ Persistent and fundamental disagreement constitutes a limiting condition of this independence; it identifies the extreme point at which democracy and diversity may become impossible to reconcile.

The fact of social disagreement plays an entirely different theoretical role within Michelman's model. This is because citizens in that model can be said to be governing themselves only to the extent that they agree with the constitutional judgments of the Court. Consensus defines and exhausts the scope of democratic self-governance. Disagreement therefore negates deinocratic legitimacy not only in extreme circumstances, but in all circumstances. Michelman's model offers no way to bridge the chasm between democratic legitimacy and the "irreparable reasonable disagreement" of modern society. This is a

28. RAWLS, supra note 19 , at 35 . 
powerful reason for rejecting Michelman's model as a convincing account of the general enterprise of democratic self-governance within contemporary states.

This enterprise, however, is not the focus of Michelman's project. He develops his model within the much narrower context of attempting to reconcile democracy with constitutionalism, as constitutionalism is embodied in the institution of judicial review. He wishes to explore this tension under the harsh (and I think accurate) assumption that much constitutional interpretation cannot plausibly be interpreted as reflecting public opinion, so that our general system of democratic participation cannot confer democratic legitimacy on one constitutional judgment or another. What remains to be considered, therefore, is how the "surmise" Michelman attributes to Brennan fares within this far more limited context.

\section{V}

Constitutionalism, at least in the United States, entails the institution of judicial review, in which courts determine whether to strike down otherwise perfectly legitimate enactments that are presumed to reflect the popular will. Sometimes, as in our First Amendment jurisprudence, these enactments are invalidated on the ground that they are inconsistent with a freedom of expression that is deemed "vital to the maintenance of our democratic institutions." ${ }^{29}$ In such circumstances the First Amendment is characterized as "the guardian of our democracy." 30 This strongly implies that within our constitutional tradition democracy can not be equated with majoritarian expressions of popular will.

Constitutional theory, therefore, must distinguish between democracy and something that we might (stipulatively) call popular sovereignty. We can define popular sovereiguty as the subordination of the state to the popular will, as that will is recognized by such procedural criteria as majoritarianism or the amendment mechanism of Article $\mathrm{V}$. The hypothetical constitutional amendment that I imagined at the beginning of this comment should be viewed as an example of popular sovereignty, not necessarily of democracy. Particular expressions of the popular will may or may not be consistent with the requirements of democratic self-governance. If the people were duly to enact a constitutional ainendment that abolishes the vote and awards lifetime and hereditary tenure to federal officials, the ainendment would exemplify popular sovereignty, but it would nevertheless be manifestly antidemocratic.

29. Schneider v. State, 308 U.S. 147, 161 (1939).

30. Brown v. Hartlage, 456 U.S. 45,60 (1982). 
This is because popular sovereignty is defined by reference to procedural criteria, whereas democracy is defined by reference to substantive values. As Michelman forcefully and correctly argues, "Democracy is a demanding normative idea, an idea with content, however uncertain or disputable that content nay be." 31 I have argued elsewhere that within our constitutional tradition, democracy is prized because of the value of collective self-governance, a value with powerful and contestable implications. ${ }^{32}$ These implications include, for example, an uncensored and perennially open-ended structure of public discourse that presumes participation by autonomous citizens. ${ }^{33}$ Courts have used the First Amendment to set aside majoritarian enactments that contradict these implications of the substantive value of democracy. In such circumstances, the tension which constitutional theory has conceptualized as between democracy and constitutionalism can be analyzed more accurately as a conflict between popular sovereignty and the constitutional ideal of democracy.

The question that Michelman wishes forthrightly and acutely to explore is the nature of a court's authority in striking down inajoritarian enactments. Michelman is surely right to argue that public opinion does not authorize the many particular interpretations of the substantive values of democracy that courts must make in order to evaluate the myriad of unforeseen circumstances that coine before them. And he is surely right to press the more fundamental claim that democracy cannot "decide the question of what democracy ineans in the first place." ${ }^{34}$ Michelman thus forces us to inquire whether constitutional judginents applying the substantive values of democracy can be rendered consistent with the self-governance required by democracy.

Michelman's model offers a cogent response to this query: Such constitutional judgments are democratic to the extent, and only to the extent, that we believe the Court has reached the right decision, because in such circumstances we will be bound by laws with which we agree. But (to appropriate Michelman's phrase) the "dark-hued inessage" of this position is that under conditions of "irreparable reasonable disagreement," constitutional adjudication applying the values of democracy will necessarily remain unreconciled with the practice of selfgovernance for large patches of the population. If we are precluded

31. Michelman, supra note 5 , at 419.

32. See Post, supra note 20 , at 184-91.

33. See id. at 186-91,272-86. The procedural account of democracy that Michelman attributes to me seems roughly to express merely one implication of the substantive idea of democracy for the regulation of public discourse. See id. at $277-78$. For a more robust account of the implications of the substantive value of democracy, see Ronald Dworkin, The Arduous Virtue of Fidelity: Originalism, Scalia, Tribe, and Nerve, 65 FordhaM L. REv. 1249, 1263-64 (1997).

34. Michelman, supra note 5 , at 419 . 
from participating in the formation of the law by which we are governed, and if we do not otherwise identify with that law, it cannot be attributed to us as our own democratic creation. As Michelman writes, "To find the laws deserving of your respect is not yet to decide the laws."3s

\section{VI}

This does not mean, however, that constitutional interpretations of the value of democracy lack legitimacy, because there are many sources of legitimacy other than democratic self-determination. Indeed, as I have argued elsewhere, the practice of democracy is always embedded within and presupposes the continued flourishing of nondemocratic forms of social organization. ${ }^{36}$ Our ongoing commitment to the value of collective self-determination must itself depend upon processes of socialization and cultural reproduction that are both nondemocratic and characteristic of the kind of social ordering that I have called "community."

Democracy orients toward the future; it concerns a people's power to decide their own fate, and it thus requires a social structure that continuously preserves the potential for renaking individual and collective identity. Community, in contrast, is retrospective; it entails a social structure that seeks to articulate and enforce social norms, which are presumed to be already constitutive of both individual and collective identity. ${ }^{38}$ Yet the open-ended future envisioned by democracy always presupposes an ongoing commitment to at least one pre-existing value, that of democracy itself. For that reason, democracy depends upon a social structure that sustains and nourishes the value of collective selfdetermination as constitutive of collective and individual identity. ${ }^{39}$

The value of collective self-determination is therefore a community norm. Like all community norms, it is reproduced by means of socialization and institutionalization. And, like all community norms, it is intrinsically contestable. ${ }^{40} \mathrm{We}$ inevitably differ about the meaning of the value of democracy, because to take a position about that meaning is to express a vision about who we are as a people. As a consequence, the

35. Id. at 427.

36. See Post, supra note 20 , at $192-93$.

37. See id. at 13-15, 188-96.

38. See id. at 52-59, 180-91.

39. This leads to what I have elsewhere called the "paradox of public discourse." In our constitutional tradition, democracy has been interpreted to suspend the enforeement within public discourse of the very community norms that sustain the practice and ongoing commitment of our culture to democracy. See id. at 13-14, 146-48.

40. See id. at 183; Robert C. Post, Community and the First Amendment, 29 ARsz. ST. LJ. 473, 476 (1997). 
boundary between democracy and popular sovereignty is always debatable. One of the most striking contributions of Michelman's essay is its dogged illumination of the paradoxical ways in which the ideal of democratic self-governance requires both popular sovereignty and limitations on that sovereignty. Ultimately, however, these limitations can have no greater warrant than our best "effort to read the Constitution in the light of what John Dewey once called 'The Great Community' of the nation."41

Of course this analysis is not confined to the First Amendment and the value of democracy. Not only is the practice of constitutional interpretation not itself grounded in democratic self-determination, bnt the specific value of democratic self-determination is only one of many values that constitutional interpretation seeks to promote. These values range from those of federalism (associated with the text of the Eleventh Amendment), to those of substantive. equality (implied by the Equal Protection Clause), to those of faimess (as embodied in the Due Process Clause), to those of liberal humanitarianism (typically located in the text of the Eighth Amendment). Most instances of lively constitutional adjudication involve the effort to peer "behind the words of the constitutional provisions" to discern the "postulates which limit and control."42 These postulates ultimately root themselves in "constitutional ideals,"43 which is to say, in interpretations of the historically fundamental norms of the national community. Taken together, these ideals comprise what may be called a national ethos. ${ }^{44}$

Judicial exposition of the national ethos flourishes in the interstices of popular sovereignty. Constitutional interpretation is always subject to revision by the arbitrary will of the people as measured by the procedure-dependent standards of Article $V$. These standards function as a rule of recognition that transforms popular opinion into positive law. The brute dictates of that law stand forth as naked and compelling. But as the immediate context of that law fades with time, and as unforeseen

41. Post, supra note 20, at 18; see also id. at 23-50; Post, supra note 40, at 482-83.

42. Principality of Monaco v. Mississippi, 292 U.S. 313, 322 (1934).

43. See Planned Parenthood of Southeastern Pa. v. Casey, 505 U.S. 833, 868 (1992) (plurality opinion).

44. See Post, supra note 20 , at $35-38,41-49$. Various ideals within the national ethos can he in tension with each other. For example, the substantive value of democracy has been interpreted to require an open-ended structure of public discourse that suspends all regulations of public discourse that impose a particular conception of national identity, including regulations that express competing eonstitutional ideals. See id. at 272-76. There is thus always a potential conflict between the implementation of the constitutional value of democracy and other constitutional values. This is illustrated by the current debate over the regulation of hate speech, which is often cast as a conflict between the First and Fourteenth Amendments. The example indicates that what traditional constitutional theory conceptualizes as a tension between democracy and constitutionalism can sometimes be seen more accurately as a conflict between the constitutional ideal of democracy and other constitutional ideals. 
applications accumulate and acquire a life of their own, the institution of judicial review has historically tended to transmute general or ambiguous constitutional language into loci of national contestable ideals. This is because we gravitate toward a vision of the rule of law that stresses practices of justification, in the process rendering constitutional law opaque to popular sovereignty. ${ }^{45}$

The Court has used familiar techniques of education, persuasion, argumentation, and inspiration to articulate constitutional ideals; it has invoked the considerable prestige of its institutional authority; and it has summoned the heavy presumption of traditional legal reasoning and commitments. It has used these resources both to consolidate existing cultural commitments and to facilitate the development of new cultural commitments. In none of these situations, however, have the Court's own constitutional interpretations exemplified the practice of democratic self-governance. They have instead deinonstrated how the law can evince and enforce ambient community norms. ${ }^{46}$ Whenever the law exercises this function in circumstances of cultural diversity, there is the potential for hegemonic domination with respect to those who do not share the cultural vision articulated by the law. ${ }^{47}$

In constitutional adjudication, this hegemony is sometimes a matter of imposing constitutional ideals upon a dissenting geographical section

45. This suggests one reason why the tension between constitutionalism and democracy can sometimes be so hard to grasp. Just as the term "democracy" can slide between the hard positivism of popular sovereignty and the soft norm of democratic self-governance, so can the term "constitutionalism" slip between the hard positivism of the law established by Article V and the soft social idealism of the national ethos. In analyzing the tension between constitionalism and democracy, one has to be very clear about the meanings of the terms being contrasted. To see how these different meanings can change the significance of the opposition between democracy and constitutionalism, imagine the following table:

\begin{tabular}{|l|c|c|}
\hline & $\begin{array}{c}\text { Constitutionalism as } \\
\text { National Ethos (Normative) }\end{array}$ & $\begin{array}{c}\text { Constitutionalism as } \\
\text { Positive Law }\end{array}$ \\
\hline $\begin{array}{l}\text { Democracy as } \\
\text { Normative Ideal }\end{array}$ & 1 & 2 \\
\hline $\begin{array}{l}\text { Democracy as } \\
\text { Popular Sovereignty }\end{array}$ & 3 & 4 \\
\hline
\end{tabular}

Questions at issue in Cell 1 will involve the conflict between the constitutional ideal of democracy and other constitutional ideals, such as those discussed in footnote 44, supra. By contrast, questions in Cell 2 will focus on the relationship between positive constitutional requirements, as for example those of Article V, and the ideal of democracy. In Cell 3 the tension between constitutionalism and democracy will encompass routine issues of constitutional adjudication, in which constitutional norms, like the ideal of democracy contained in the First Amendment, are pitted against majoritarian enactments. Finally, issues in Cell 4 will revolve around matters of positive institutional design, as for example, the relative advantages and disadvantages of majoritarianism and super-majoritarianism.

46. For other examples of this function of law, sce Post, supra note 20, at 51-116.

47. See id. at 3-4, 64-67, 89-116. 
of the nation, as happened in Brown v. Board of Education. ${ }^{48}$ Or this hegemony can involve the attempt to inpose generational (or perhaps class) ideals on hostile segments of the population, as occurred during the constitutional crisis of the New Deal. When the Court chooses to press a particular vision of the national ethos in the face of opposition, it is rendered vulnerable to political reprisal, which can take such various forms as civil disobedience, hostile Presidential appointments, or constitutional amendments. The difficulty and necessity of navigating through such dangers is why it is said that Justices of the Supreine Court must be "statesmen." 49

\section{VII}

Justice Brennan was a great judicial statesman. He was well aware of the limits and obligations of his powerful position; he knew when and where to compromise. But he was also, and most importantly, a supremely disciplined and forceful expositor of constitutional ideals, especially the ideal of democratic self-governance. Brennan's influence on First Amendment jurisprndence is second to none. I agree entirely with Michelman's assessment:

Brennan saw his Court as invested with authority and responsibility to interpret for the country a procedure-independent standard of rightness, justice, and democracy for its political regiune. But it is enormously to his credit that he saw the Court as thus empowered only as long as it exercised its power with a view to protecting and expanding the rights and opportunities of everyone to impress their views upon the Court and other social authorities, democratically. ${ }^{50}$

Brennan's achievement, however, cannot be characterized as "selfgovernment through democracy." 51 Brennan expounded a convincing account of the constitntional meaning of democracy, and he successfully translated much of that account into constitntional law. Although those of us who share Brennan's perspective have reason to identify with this law, the same can not be said of those who disagree with it. It is certainly ironic that Brennan's constitutional judgments created freedoms that enhance the democratic self-governance of all, even of those who disagree with him about the meaning of democracy. Yet this irony does not justify characterizing these judgments as themselves exemplifying the self-governance of those who dissent from them. The

48. 347 U.S. 483 (1954).

49. See, e.g., Felix Frankfurter, The Court and Statesmanship, in LAW AND PoL1TICs 34 (Archibald MacLeish \& E.F. Prichard, Jr. eds., 1939).

50. Michelman, supra note 5 , at 426 .

51. Id. 
self-governance which these dissenters enjoy as a result of Brennan's work is instead merely a reason that can be proffered to enlist their support of Brennan's constitutional vision.

That vision enjoys the status of a (legally) authoritative articulation of national identity. As such, it forms part of an ongoing national process of community self-definition, ${ }^{52}$ a process in which we are all implicated and in which the contributions of constitutional theory can also play some small role. All the more reason, then, to praise in this symposium the justness and profundity of Brennan's jurisprudence.

52. On the difference between democratic self-governance and community self-definition, see Robert C. Post, Subsidized Speech, 106 YALE L.J. 151, 192-93 (1996). 
CALIFORNIA LAW REVIEW 